\title{
ANALISIS PERBANDINGAN KONTRIBUSI PAJAK DAERAH TERHADAP PENDAPATAN ASLI DAERAH (PAD) DI KOTA MANADO DAN KOTA BITUNG (Periode 2012-2016)
}

\author{
Prety $^{1}$, Hendrik Manosoh $^{2}$, Treesje Runtu ${ }^{3}$ \\ ${ }^{1,2,3}$ Fakultas Ekonomi dan Bisnis, Jurusan Akuntansi, Universitas Sam Ratulangi, Jl. Kampus Bahu, Manado, \\ 95115, Indonesia \\ E-mail : prettykwl@gmail.com
}

\begin{abstract}
Local Taxes is one of the sources of Local Own Revenues (PAD) to finance regional development and operational implementation of local government, Populated will depend much on the local government due to regional autonomy. To that end Local Government must be as much as possible sources of Revenue Original Region. PAD is one of the indicators in the success of regional autonomy. The higher the PAD the higher the ability of local governments to finance their own needs. The purpose of this research is to know how big the benefit to the original income of Manado City and Bitung City during the last year that is year 2012-2016. The research method used is descriptive quantitative method. The results can be drawn back Manado City is superior in contributing from local taxes to the original income in the appeal of the city of Bitung. This is not wrong from the average contribution of total local taxes to PAD in Manado City amounted to 71.39\%. Meanwhile, the PAD in Bitung City is only $42.32 \%$.
\end{abstract}

Keywords: contributions, local revenue, local taxes

\section{PENDAHULUAN}

Pendapatan Asli Daerah merupakan salah satu sumber pembiayaan daerah yang utama dalam rangka pelaksanaan desentralisasi. Karena penyelenggaraan pemerintahan di daerah akan terlaksana dengan baik apabila didukung oleh dana yang memadai, disamping dana yang berasal dari pusat. Namun demikian meskipun terdapat bantuan transfer dana dari pusat, daerah diharapkan tidak selalu bergantung kepada pusat dalam artian daerah harus mampu menggali sumber-sumber pembiayaan yang berasal dari daerahnya sendiri. Sumber-sumber penerimaan daerah yang potensial harus digali secara maksimal namun tetap dalam koridor peraturan perundang-undangan yang berlaku.

Berdasarkan Undang-Undang nomor 28 tahun 2009 tentang perubahan atas UU Nomor 34 tahun 2000 tentang pajak daerah dan retribusi daerah pasal 1, "Pajak daerah adalah Iuran wajib yang dilakukan oleh orang pribadi dan badan kepada daerah tanpa imbalan langsung yang seimbang, yang dapat dipaksakan berdasarkan peraturan perundang-undangan yang berlaku, yang digunakan untuk membiayai penyelanggaraan pemerintah daerah dan pembangunan daerah". Dari pengertian di atas maka dapat disimpulkan bahwa pajak daerah adalah penerimaan daerah yang berasal dari orang pribadi atau badan yang sifatnya dapat dipaksakan. (yuridis) berdasarkan peraturan perundang-undangan dan tidak ada kontraprestasi/imbalan secara langsung serta digunakan untuk membiayai pemerintah dan pembangunan daerah. Wewenang pemungutan pajak daerah ada pada pemerintah daerah yang pelaksanaannya dilakukan oleh Dinas Pendapatan Daerah. 
Kota Manado dalam rangka meningkatkan pertumbuhan otonomi daerah yang lebih nyata, maka Kota Manado memiliki banyak potensi dan sumber daya yang dapat digali dan diolah untuk dijadikan sebagai sumber pendapatan daerahnya. Kota Manado masih perlu untuk mengoptimalkan sumber-sumber potensi daerahnya dalam meningkatkan PAD khususnya pajak daerah.

Otonomi daerah juga dilakukan oleh Kota Bitung. Sebagai daerah otonom yang baru, Kota Bitung dituntut mengelola dan mengurus keuangan sendiri. Pemerintah daerah dituntut untuk mengelola keuangan secara ekonomis, efisien, efektif, transparansi, akuntabilitas dan berkeadilan. Ini menjadi tantangan bagi pemerintah Kota Bitung sebagai Kota yang baru untuk dapat meningkatkan PAD khususnya pajak daerah melalui potensi dan sumber daya yang ada. Pemerintah daerah Kota Manado dan Kota Bitung yang memiliki banyak potensi dan sumber daya, dituntut untuk dapat mengelola Pajak Daerahnya dengan baik sebagai salah satu Pendapatan Asli Daerahnya.

Berdasarkan uraian diatas, maka penulis tertarik membuat penelitian dengan judul "Analisis Perbandingan Kontribusi Pajak Daerah Terhadap Pendapatan Asli Daerah Di Kota Manado Dan Kota Bitung Periode 2012-2016”.

\section{TINJAUAN PUSTAKA}

\subsection{Konsep Akuntansi}

Pengertian Akuntansi menurut beberapa sumber: Menurut Weygandt, Kimmel, dan Kieso (2012:4) Akuntansi adalah suatu sistem informasi yang mengidentifikasi, mencatat, dan mengkomunikasikan peristiwa-peristiwa ekonomi dari suatu organisasi kepada para pengguna yang berkepentingan.

\subsection{Konsep Pajak}

Mardiasmo (2011:1) Pajak adalah iuran rakyat kepada kas negara berdasarkan Undang Undang (yang dapat dipaksakan) dengan tiada mendapat jasa timbal (kontraprestasi) yang langsung dapat ditunjukkan dan yang digunakan untuk membayar pengeluaran umum.

\subsection{Otonomi Daerah}

Pengertian otonomi daerah yang berdasarkan Undang-Undang No.32 Tahun 2004 tentang Pemerintahan Daerah, dalam Pasal 1 disebutkan bahwa otonomi daerah yaitu hak, wewenang, dan kewajiban daerah otonom untuk mengatur dan mengurus sendiri urusan pemerintahan dan kepentingan masyarakat setempat sesuai dengan peraturan perundang-undangan.

\subsection{Pendapatan Asli Daerah}

Menurut Undang-Undang No.32 Tahun 2004 tentang pemerintahan daerah menyebutkan bahwa pendapatan daerah yaitu semua hak daerah yang diakui sebagai penambah nilai kekayaan bersih dalam periode anggaran tertentu. Sedangkan menurut Undang-Undang No.33 Tahun 2004 tentang Perimbangan Keuangan Antara Pusat dan Daerah Pasal 1 angka 18 menyebutkan bahwa "Pendapatan asli daerah, selanjutnya disebut PAD adalah pendapatan yang diperoleh daerah yang dipungut berdasarkan peraturan daerah sesuai dengan peraturan perundang-undangan". 


\subsection{Penelitian Terdahulu.}

Dini Anggreini (2012) dalam penelitian berjudul Kontribusi Pajak Daerah Terhadap Pendapatan Asli Daerah Tahun 2010 dan 2011 (Studi Kasus Dinas Pendapatan Daerah Kabupaten Sleman). Hasil Penelitian menunjukkan Tingkat realisasi Pajak Daerah kabupaten Sleman tahun 2010 lebih rendah daripada tingkat pencapaian realisasi PAD. Pada tahun 2011 realisasi pajak daerah kabupaten sleman lebih rendah daripada realisasi PAD. Terdapat beberapa daerah yang tidak memiliki kontribusi melalui pajak daerah tertentu. Kontribusi penerimaan Pajak Daerah terhadap PAD kabupaten Sleman pada tahun 2010 sebesar 49,321\% meningkat menjadi $62,833 \%$ pada tahun 2011. Hambatan utama yang dihadapi Dinas Pendapatan Daerah Kabupaten Sleman dalam pemungutan pajak daerah yaitu masih banyaknya wajib pajak yang tidak taat membayar pajak.

Maxwel Taluke (2013) dalam penelitian berjudul Analisis Kontribusi Penerimaan Pajak Daerahcdan Retribusi Daerah Terhadap Pendapatan Asli Daerah (PAD) Di Kabupaten Halmahera Barat. Hasil penelitian Pajak dan Retribusi Daerah merupakan sumber pendapatan daerah yang paling besar di bandingkan dengan Pendapatan Asli Daerah lainya. Hal ini di buktikan dengan kontribusi Pajak Daerah terhadap PAD ratarata sebesar 14,4\% dan kontribusi Retribusi Daerah terhadap PAD Kabupaten Halamahera Barat rata-rata sebesar 34,2\%. Retribusi daerah lebih besar membrikan kontribusi terhadap Pendapatan Asli Daerah (PAD) dari pada Pajak Daerah.

\section{METODE PENELITIAN}

\subsection{Jenis dan sumber data}

Dalam penelitian ini penulis menggunakan penelitian deskriptif, yaitu dengan cara mengumpulkan, mengklasifikasikan, menganalisis, dan menginterpretasikan data-data yang diperoleh dari perusahaan/instansi sehingga dapat memberikan gambaran dengan keadaan yang sebenarnya.

\subsection{Tempat Dan Waktu Penelitian}

Tempat penelitian yang dipilih oleh penulis adalah pada Dinas Pendapatan Daerah Kota Manado dan Dinas Pendapatan Daerah Kota Bitung. Proses pengumpulan dan pengolahan data untuk penelitian ini memakan waktu 2 (dua) bulan yaitu dimulai dari bulan Mei s/d Juli 2017.

\subsection{Prosedur Penelitian}

1. Mengajukan permohonan penelitian

2. Disposisi pimpinan

3. Pengumpulan data

4. Analisa data penelitian

5. Analisa penerapan 


\subsection{Metode Pengumpulan Data}

\subsubsection{Jenis Data}

Data adalah kumpulan informasi yang diperoleh dari suatu pengamatan, dapat berupa angka, lambang atau sifat. Jenis data menurut sifatnya terbagi 2 (dua) yaitu data kuantitatif dan data kualitatif.

1. Data kuantitatif adalah data yang berupa bilangan, nilainya biasa berubah-ubah atau bersifat variatif.

2. Data kualitatif adalah data yang bukan merupakan bilangan, tetapi berupa ciri-ciri, sifatsifat, keadaan, atau gambaran dari kualitas objek yang diteliti.

Dalam penelitian ini penulis menggunakan kedua jenis data tersebut dalam penulisan skripsi ini, yaitu data kualitatif dalam hal ini berupa gambaran umum wilayah Kota Manado dan Kota Bitung dan data kuantitatif adalah berupa total realisasi Pendapatan Asli Daerah, Pajak Daerah dan jenis-jenis Pajak Daerah pemerintah Kota Manado dan Kota Bitung tahun 2012-2016.

\subsubsection{Sumber Data}

Sumber data penelitian dibagi dua yaitu sebagai berikut.

1. Data primer adalah data yang didapatkan langsung melalui wawancara.

2. Data sekunder adalah data yang didapatkan dalam buku-buku literatur, jurnal, serta bahan-bahan informasi lainnya yang berhubungan dengan materi yang dibahas oleh penulis.

Data yang digunakan dalam penelitian ini berupa data sekunder yang diperoleh pada Dinas Pendapatan Daerah Kota Manado dan Dinas Pendapatan Daerah Kota Bitung.

\subsection{Metode Analisis}

Sesuai dengan tujuan dari penelitian ini maka, metode analisis yang digunakan adalah metode analisis deskriptif kuantitatif yang bertujuan untuk mendapatkan gambaran yang lebih jelas dan terperinci mengenai suatu keadaan berdasarkan data atau informasi yang telah didapatkan kemudian dikumpulkan sehingga didapatkan informasi yang diperlukan untuk menganalisa masalah yang ada, dalam hal ini memberikan gambaran berapa besar kontribusi total pajak daerah terhadap Pendapatan Asli Daerah, kontribusi setiap jenis pajak daerah terhadap total pajak daerah dan kontribusi setiap jenis pajak daerah terhadap PAD di Kota Manado dan Kota Bitung. Semua hasil analisis itu disajikan dalam bentuk tabel-tabel perhitungan. 


\section{HASIL ANALISIS DAN PEMBAHASAN}

\subsection{Hasil analisis}

4.1.1. Realisasi Penerimaan Pendapatan Asli Daerah (PAD) di Kota Manado dari Tahun 2012 - 2016

Tabel 4.1 Realisasi Penerimaan PAD di Kota Manado Tahun 2012 -2016

\begin{tabular}{|c|c|c|c|c|c|}
\hline \multirow{2}{*}{ URAIAN } & \multicolumn{5}{|c|}{$\begin{array}{c}\text { TAHUN } \\
\text { (Rp) }\end{array}$} \\
\hline & 2012 & 2013 & 2014 & 2015 & 2016 \\
\hline Total PAD & 178.429.310.832 & 215.871.042.643 & 263.392.296.958 & 289.462.741.463 & 306.453.382.648 \\
\hline Total Pajak Daerah & 136.226.412.384 & 156.424.112.594 & 187.303.746.686 & 205.090 .034 .810 & 222.234.798.430 \\
\hline Pajak Hotel & 14.372 .806 .936 & 17.129 .842 .717 & 17.449 .408 .116 & 18.168 .799 .451 & 25.425 .453 .862 \\
\hline Pajak Restoran & 35.375 .758 .371 & 38.438 .945 .114 & 40.401 .504 .799 & 47.469.492.846 & 60.607 .630 .932 \\
\hline Pajak Hiburan & 5.498 .904 .721 & 7.195 .289 .512 & 7.280 .563 .807 & 9.039 .266 .285 & 11.012 .273 .849 \\
\hline Pajak Reklame & 2.760 .872 .514 & 3.036 .969 .391 & 3.261 .324 .364 & 6.299.940.097 & 8.922 .985 .528 \\
\hline Pajak Parkir & 3.273 .738 .607 & 6.030 .222 .350 & 6.054.974.717 & 7.053 .796 .873 & 8.429 .890 .942 \\
\hline Pajak Air Tanah & 457.154 .778 & 571.743 .810 & 1.052 .785 .600 & 1.412 .980 .676 & 1.056 .966 .368 \\
\hline Pajak Burung Walet & - & - & 1.480 .000 & 4.150 .000 & 3.760 .000 \\
\hline $\begin{array}{c}\text { Pajak Mineral bukan } \\
\text { Logam dan Batuan }\end{array}$ & 12.490 .678 & 30.736 .336 & 53.124 .391 & 36.277 .500 & - \\
\hline Pajak BPHTB & 41.846 .497 .614 & 44.836 .858 .810 & 38.091 .690 .080 & 40.580 .747 .667 & 28.630 .670 .885 \\
\hline $\begin{array}{c}\text { Pajak Penerangan Jalan } \\
\text { (PPJ) PLN }\end{array}$ & 32.628 .188 .165 & 39.153.504.554 & 44.916 .556 .996 & 50.557 .318 .490 & 50.435 .147 .574 \\
\hline $\begin{array}{c}\text { Pajak Bumi dan } \\
\text { Bangunan Pedesaan } \\
\text { dan Perkotaan (P@) }\end{array}$ & - & - & 28.740 .333 .816 & 24.467 .264 .925 & 27.710 .018 .490 \\
\hline
\end{tabular}

Sumber : Data DinasPendapatan Daerah Kota Manado Tahun 2012-2016

Pada Tabel 4.1 menunjukkan perkembangan besarnya Total Realisasi Penerimaan Pendapatan Asli Daerah (PAD) di Kota Manado dari tahun 2012-2016. Pada tahun 2012 s/d 2013 penerimaan PAD bersumber dari 9 (sembilan) jenis pajak daerah walaupun sudah ditargetkan pada sepuluh jenis pajak daerah namun pajak burung walet untuk tahun 2012 dan 2013 masih nihil. Kemudian pada tahun 2014 s/d 2016 pajak burung sarang walet telah menambah penerimaan PAD Kota Manado dimana pada tahun 2014 ke 2015 penerimaan PAD Kota Manado melalui pajak burung sarang walet mengalami peningkatan sedangkan untuk penerimaan di tahun 2016 mengalami penurunan penerimaan PAD Kota Manado dari pajak Burung Sarang Walet. Mulai pada tahun 2014 mendapat ketambahan 1 (satu) jenis pajak daerah untuk penerimaan PAD Kota Manado yaitu Pajak Bumi dan Bangunan Pedesaan dan Perkotaan (P2) yang besarnya penerimanan dari jenis pajak ini berfluktuasi. Pada tahun 2016 terjadi peningkatan penerimaan PAD Kota Manado walaupun penerimaan dari Pajak Mineral Bukan Logam dan Batuan adalah nihil. Selanjutnya penerimaan dari Pajak BPHTB Kota Manado terjadi peningkatan dari tahun 2012 ke tahun 2013 tetapi selanjutnya mengalami penurunan dari tahun 2014 s/d tahun 2016 walaupun penerimaan PAD Kota Manado secara keseluruhan dari tahun 2012 s/d 2016 mengalami peningkatan dari tahun ke tahun.

Total Realisasi Penerimaan PAD untuk tahun 2012 di Kota Manado sebesar Rp 178.429.310.832.- dan pada tahun 2013 Penerimaan PAD Kota Manado meningkat menjadi sebesar Rp 215.871.042.643.- kemudian ditahun 2014 Penerimaan PAD Kota Manado meningkat lagi menjadi sebesar Rp.263.392.296.958.- selanjutnya untuk tahun 2015 dan 
2016 Penerimaan PAD Kota Manado terus menunjukkan adanya peningkatan, dimana di tahun 2015 menjadi sebesar Rp 289.462.741.483.- dan untuk tahun 2016 menjadi sebesar Rp.306.453.382.648.-

\subsubsection{Realisasi Penerimaan Pendapatan Asli Daerah (PAD) di Kota Bitung Tahun 2012 $-2016$}

Tabel 4.2. Realisasi Penerimaan PAD di Kota Bitung tahun 2012 - 2016

\begin{tabular}{|c|c|c|c|c|c|}
\hline \multirow{2}{*}{ URAIAN } & \multicolumn{5}{|c|}{$\begin{array}{c}\text { TAHUN } \\
(\mathbf{R p})\end{array}$} \\
\hline & 2012 & 2013 & 2014 & 2015 & 2016 \\
\hline Total PAD & 38.435.120.911,59 & $55.199 .680 .147,00$ & 83.520.151.103,00 & 106.133.530.054,30 & 82.886.473.410,63 \\
\hline $\begin{array}{c}\text { Total Pajak } \\
\text { Daerah }\end{array}$ & 17.723.643.955,00 & 26.162.693.540,00 & 33.493.759.019,00 & 37.360.100.376,00 & 35.463.308.256,00 \\
\hline Pajak Hotel & 1.457.025.208,00 & $1.800 .124 .842,00$ & 2.079.360.152,00 & $1.695 .607 .242,00$ & 2.077.088.894,00 \\
\hline $\begin{array}{c}\text { Pajak } \\
\text { Restoran }\end{array}$ & $1.805 .123 .000,00$ & 2.307.701.798,00 & $2.584 .314 .625,00$ & 2.606.105.374,00 & $2.623 .122 .477,00$ \\
\hline $\begin{array}{c}\text { Pajak } \\
\text { Hiburan }\end{array}$ & $198.637 .081,00$ & $350.017 .975,00$ & $345.389 .741,00$ & $286.354 .760,00$ & $353.565 .459,00$ \\
\hline $\begin{array}{c}\text { Pajak } \\
\text { Reklame }\end{array}$ & $756.234 .975,00$ & $809.534 .178,00$ & $838.162 .296,00$ & $836.869 .454,00$ & $1.130 .347 .349,00$ \\
\hline $\begin{array}{c}\text { Pajak } \\
\text { Penerangan } \\
\text { Jalan } \\
\end{array}$ & 8.089.693.620,00 & 9.879.134.934,00 & $12.776 .439 .417,00$ & $12.829 .757 .492,00$ & $12.522 .804 .740,00$ \\
\hline $\begin{array}{l}\text { Pajak Air } \\
\text { Tanah }\end{array}$ & $639.219 .514,00$ & $789.506 .559,00$ & $907.651 .894,00$ & $1.315 .038 .395,00$ & $1.460 .656 .022,00$ \\
\hline $\begin{array}{c}\text { Pajak Mineral } \\
\text { Bukan Logam } \\
\text { dan Batuan }\end{array}$ & $556.225 .775,00$ & $640.789 .991,00$ & $317.167 .164,00$ & $671.637 .571,00$ & $505.573 .490,00$ \\
\hline $\begin{array}{c}\text { Bea } \\
\text { Perolehan } \\
\text { Hak Atas } \\
\text { Tanah dan } \\
\text { Bangunan } \\
\end{array}$ & 4.221.484.782,00 & $9.585 .883 .263,00$ & 4.099.693.283,00 & $6.254 .509 .434,00$ & 4.649.941.160,00 \\
\hline Pajak Parkir & - & - & $2.610 .000,00$ & $22.932 .900,00$ & $22.981 .500,00$ \\
\hline $\begin{array}{l}\text { Pajak Sarang } \\
\text { Burung Walet }\end{array}$ & & & $5.300 .000,00$ & $4.100 .000,00$ & $4.100 .000,00$ \\
\hline $\begin{array}{c}\text { Pajak Bumi } \\
\text { dan } \\
\text { Bangunan } \\
\text { Pedesaan dan } \\
\text { Perkotaan }\end{array}$ & & & $9.537 .670 .447,00$ & $10.837 .187 .754,00$ & $10.113 .127 .165,00$ \\
\hline
\end{tabular}

Sumber : Data DinasPendapatan Daerah Kota Bitung Tahun 2012-2016

Tabel 4.2 menunjukkan Realisasi Penerimaan Pendapatan Asli Daerah (PAD) di Kota Bitung dari tahun 2012-2016. Pada tahun 2012 dan 2013 penerimaan PAD Kota Bitung bersumber dari 8 (delapan) jenis pajak daerah sedangkan pada tahun 2014 s/d 2016 penerimaan PAD Kota Bitung jenis pajak daerahnya bertambah menjadi 11 jenis pajak daerah. Secara keseluruhan Penerimaan PAD Kota Bitung dari tahun 2012 s/d 2015 terjadi peningkatan dari tahun ke tahun namun di tahun 2016 Penerimaan PAD kota Bitung mengalami penurunan.

Penerimaan PAD Kota Bitung yang bersumber dari Pajak Hotel, Pajak Hiburan, Pajak Mineral Bukan Logam dan Batuan , BPHTB dan Pajak Sarang Burung Walet mengalami fluktuasi dari tahun ketahun. Adapun Penerimaan PAD Kota Bitung pada tahun 2012 sebesar Rp.38.435.120.911,59.- dan pada tahun 2013 adanya peningkatan menjadi sebesar Rp.55.199.680.147,00.- kemudian di tahun 2014 Penerimaan PAD Kota Bitung meningkat lagi menjadi sebesar Rp.83.520.151.103,00.- selanjutnya di tahun 2015 penerimaan PAD Kota Bitung terus menunjukkan mengalami peningkatan menjadi sebesar Rp.106.133.530.054,30.Namun pada tahun 2016 penerimaan PAD kota Bitung mengalami penurunan menjadi sebesar Rp.82.886.473.410,63.-. 


\subsection{Pembahasan}

Dari hasil penelitian yang dilakukan, maka selanjutnya dapat memberikan uraian yang lebih rinci dalam pembahasan tentang Perbandingan Analisis Kontribusi Pajak Daerah terhadap Penerimaan Pendapatan Asli Daerah (PAD) di Kota Manado dan Kota Bitung dari tahun 20122016 sebagai berikut:

\subsubsection{Persentase Kontribusi Pajak Daerah terhadap PAD di Kota Manado Tahun Periode 2012-2016 \\ Kontribusi digunakan untuk mengetahui sejauh mana besarnya kontribusi dalam hal ini} pajak daerah memberikan sumbangan dalam penerimaan Pendapatan Asli Daerah. Untuk itu dilakukan dengan cara membandingkan penerimaan Pajak Daerah periode tertentu dengan penerimaan Pendapatan Asli Daerah pada periode tertentu pula.

Tabel 4.3. Persentase Kontribusi Total Pajak Daerah terhadap Total PAD di Kota Manado Tahun Periode 2012-2016

\begin{tabular}{|r|c|c|c|}
\hline Tahun & $\begin{array}{c}\text { PAD } \\
(\mathbf{R p})\end{array}$ & $\begin{array}{c}\text { Pajak Daerah } \\
(\mathbf{R p})\end{array}$ & $\begin{array}{c}\text { Kontribusi } \\
(\%)\end{array}$ \\
\hline 2012 & 178.429 .310 .832 & 136.226 .412 .384 & 76,35 \\
\hline 2013 & 215.871 .042 .643 & 156.424 .112 .594 & 72,46 \\
\hline 2014 & 263.392 .296 .958 & 187.303 .746 .686 & 64,70 \\
\hline 2015 & 289.462 .741 .463 & 205.090 .034 .810 & 70.85 \\
\hline 2016 & 306.453 .382 .648 & 222.234 .798 .430 & 72,58 \\
\hline \multicolumn{4}{|c|}{ Rata-rata per tahun } \\
\hline
\end{tabular}

Sumber: Dinas Pendapatan Daerah Kota Manado, 2017 


\subsubsection{Persentase Kontribusi Jenis-jenis Pajak Daerah terhadap PAD di Kota Manado Tahun Periode 2012-2016}

Tabel 4.4. Persentase Kontribusi Jenis-jenis Pajak Daerah terhadap PAD di Kota Manado Tahun Periode 2012-2016

\begin{tabular}{|c|c|c|c|c|c|c|c|}
\hline \multirow[t]{2}{*}{ Jenis-Jenis Pajak } & \multicolumn{5}{|c|}{$\begin{array}{c}\text { Tahun } \\
(\%)\end{array}$} & \multirow{2}{*}{$\begin{array}{c}\text { Total } \\
(\%)\end{array}$} & \multirow{2}{*}{$\begin{array}{c}\text { Rata- } \\
\text { rata } \\
(\%) \\
\end{array}$} \\
\hline & 2012 & 2013 & 2014 & 2015 & 2016 & & \\
\hline Pajak Hotel & 8,055 & 7,935 & 6,625 & 6,277 & 8,297 & 37,189 & 7,4378 \\
\hline Pajak Restoran & 19,826 & 17,806 & 15,339 & 16,399 & 19,777 & 89,147 & 17,8294 \\
\hline Pajak Hiburan & 3,081 & 3,333 & 2,764 & 3,123 & 3,593 & 15,894 & 3,1788 \\
\hline Pajak Reklame & 1,547 & 1,407 & 1,238 & 2.176 & 2.912 & 9,280 & 1,8560 \\
\hline Pajak Parkir & 1,834 & 2,793 & 2,299 & 2.437 & 2,751 & 12,114 & 2,4228 \\
\hline Pajak Air Tanah & 0,256 & 0,265 & 0,399 & 0,488 & 0,345 & 1,753 & 0,3506 \\
\hline Pajak Burung Walet & - & - & 0,001 & 0,001 & 0,001 & 0,003 & 0,0010 \\
\hline Pajak Mineral Bukan Logam dan Batuan & 0,007 & 0,014 & 0,020 & 0,013 & - & 0,054 & 0,0108 \\
\hline $\begin{array}{l}\text { Bea Perolehan Hak Atas Tanah Dan Bangunan } \\
\text { (BPHTB) }\end{array}$ & 23,452 & 20,770 & 14,462 & 14,019 & 9,343 & 82,046 & 16,4092 \\
\hline Pajak Penerangan Jalan & 18,286 & 18,137 & 17,053 & 17,466 & 16,458 & 87,400 & 17,4800 \\
\hline Pajak Bumi dan Bangunan P2 & - & - & 10,912 & 8,453 & 9,042 & 28.4070 & 9,4690 \\
\hline
\end{tabular}

Sumber: Dinas Pendapatan Daerah Kota Manado, data diolah, 2017

\subsubsection{Persentase Kontribusi Jenis-Jenis Pajak Daerah terhadap Total Pajak Daerah di Kota ManadoTahun periode 2012-2016}

Tabel 4.5 Persentase Kontribusi Jenis-Jenis Pajak Daerah terhadap Total Pajak Daerah di Kota ManadoTahun periode 2012-2016

\begin{tabular}{|l|r|r|r|r|r|r|r|}
\hline \multirow{2}{*}{ Jenis-Jenis Pajak } & \multicolumn{9}{c|}{ Tahun } & \multirow{2}{*}{ Total } & \multirow{2}{*}{ Rata-Rata } \\
\cline { 2 - 7 } & 2012 & \multicolumn{1}{|c|}{2013} & 2014 & \multicolumn{1}{c|}{2015} & \multicolumn{1}{c|}{2016} & & \\
\hline Pajak Hotel & 10,550 & 10,950 & 9,316 & 8,859 & 11,441 & 51,116 & 10,223 \\
\hline Pajak Restoran & 25,968 & 24,573 & 21,570 & 23,146 & 27,272 & 122,529 & 24,506 \\
\hline Pajak Hiburan & 4,037 & 4,560 & 3,887 & 4,407 & 4,955 & 21,846 & 4,369 \\
\hline Pajak Reklame & 2,027 & 1,941 & 1,741 & 3,072 & 4,015 & 12,796 & 2,559 \\
\hline Pajak Parkir & 2,404 & 3,855 & 3,233 & 3,439 & 3,793 & 16.724 & 3,345 \\
\hline Pajak Air Tanah & 0,336 & 0,365 & 0,562 & 0,689 & 0,476 & 2,428 & 0,486 \\
\hline Pajak Burung Walet & - & - & 0,001 & 0,002 & 0,002 & 0,005 & 0,0016 \\
\hline Pajak Mineral Bukan Logam dan Batuan & 0,009 & 0,020 & 0,028 & 0,018 & - & 0,075 & 0,0606 \\
\hline Bea Perolehan Hak Atas Tanah Dan Bangunan & 30,718 & 28,472 & 20,337 & 19,787 & 12,883 & 112,197 & 22,439 \\
\hline Pajak Penerangan Jalan & 23,951 & 25,030 & 23,981 & 24,651 & 22,695 & 120,308 & 24,062 \\
\hline Pajak Bumi Dan Bangunan P2 & - & - & 15,344 & 11,930 & 12,469 & 39,743 & 13,248 \\
\hline
\end{tabular}

Sumber: Dinas Pendapatan Daerah Kota Manado, data diolah, 2017

\section{KESIMPULAN DAN SARAN 5.1 Kesimpulan}

Berdasarkan analisis perbandingan kontribusi pajak daerah terhadap Pendapatan Asli Daerah di Kota Manado dan Kota Bitung pada tahun 2012-2016, maka diperoleh beberapa kesimpulan, yaitu:

1. Rata-rata Kontribusi total pajak daerah terhadap PAD di Kota Manado adalah sebesar $71,39 \%$. Sedangkan rata-rata Kontribusi pajak daerah terhadap PAD di Kota Bitung adalah sebesar $42,320 \%$.

2. Kontribusi jenis-jenis pajak daerah terhadap PAD yang paling tinggi untuk Kota Manado adalah Pajak Restoran yaitu rata-rata sebesar 17,830 \% tiap tahunnya, 
sedangkan Kota Bitung yaitu Pajak Penerangan Jalan rata-rata sebesar 16,288 \% tiap tahunnya dan yang paling rendah berkontribusi di Kota Manado adalah Pajak Sarang Burung Walet yaitu rata-rata sebesar 0,001\% ditiap tahunnya, sedangkan untuk di Kota Bitung adalah Pajak Burung Sarang Walet yaitu rata-rata sebesar 0,005\%.

3. Kota Bitung adalah Pajak Burung Sarang Walet yaitu rata-rata sebesar $0,008 \%$.

4. Dari data tersebut dapat disimpulkan bahwa Kota Manado lebih unggul dalam memberikan kontribusi dari Pajak Daerah terhadap Pendapatan Asli Daerah di banding Kota Bitung.

\subsection{Saran}

1. Pemerintah Kota Manado dan Kota Bitung perlu untuk; menggunakan teknik analisa data yang digunakan dalam penelitan yaitu analisa persentase kontribusi sebagai bentuk informasi data dalam membuat keputusan kedepannya; memperluas basis penerimaan pajak melalui identifikasi pembayar pajak baru; meningkatkan efisiensi; penekanan biaya pemungutan serta memberikan sosialisasi pembayaran pajak di tiap daerah guna peningkatan Pendapatan Asli Daerah khususnya Penerimaan Pajak Daerah.

2. Untuk peneliti selanjutnya diharapkan agar dapat menjadikan metode analisis komparatif seperti ini sebagai cara untuk membandingkan dua daerah kabupaten/kota dalam rangka peningkatan penerimaan Pajak Daerah serta Pendapatan Asli Daerah masing-masing dalam melakukan penelitian selanjutnya.

\section{DAFTAR PUSTAKA}

Adelia Shabrina Prameka, (2013). Kontribusi Pajak Daerah Dan Retribusi Daerah Terhadap Pendapatan Asli Daerah (PAD) Kabupaten Malang. Universitas Brawijaya. Jurnal. Malang.

Anggraeni Dina 2010, Analisis Pengaruh Penerimaan Pajak Daerah dan Retribusi Daerah Terhadap Peningkatan Pendapatan Asli Daerah (PAD). Jurnal. Bengkulu

Arditia Reza, (2012). Analisis Kontribusi Dan Efektivitas Pajak Daerah Sebagai Sumber Pendapatan Asli Daerah kota Surabaya. Jurnal. Surabaya.

Azhari Aziz Samudra, M.Si. 2015, Perpajakan Di Indonesia: Keuangan, Pajak dan retribusi Daerah, Penerbit PT Raja Grafindo Persada, Jakarta.

Beigi M, Rajab, (2013). The analysis of the effect of tax on profitability indices in listed companies of Tehran Stock Exchange. International Journal. Iran.

Dhananjaya , I Gede Oka 2014. Perbandingan Efektivitas Dan Kontribusi Pajak Daerah Pada Pendapatan Asli Daerah. Jurnal. Bali

Hoque, Zahirul And Adams. 2008. Measuring Public Parfomance: A Study Of Government Departements In Australia. International Journal. Australia

Kambu Susi Susanti, 2014. Kontribusi Pajak Daerah Terhadap PendapatanAsli Daerah Kabupaten Sorong. Jurnal. Manado.

Kovács Gábor. 2009. Local taxes: Theory and the practice. International Journal. Hungary.

Marihot Pahala Siahaan. 2010. Hukum Pajak Elementer Konsep Dasar Perpajakan Indonesia. Yogyakarta : Graha Ilmu.

Mardalis. 2003. Metode Penelitian: Suatu Pendekatan Proposal. Jakarta: Bumi Aksara.

Mardiasmo, 2011. Perpajakan Edisi Revisi 2011, Penerbit ANDI Yogyakarta. 